DO: $10.1515 /$ ausal-2015-0004

\title{
Milling technological experiments to reduce Fusarium toxin contamination in wheat
}

\author{
A.Véha \\ e-mail: veha@mk.u-szeged.hu \\ T. Bartók \\ e-mail: bartok@mk.u-szeged.hu
}

\author{
P. Szabó \\ e-mail: szabo@mk.u-szeged.hu \\ E. Gyimes \\ e-mail: gyimes@mk.u-szeged.h
}

\begin{abstract}
We examine 4 different DON-toxin-containing (0.74-1.15 $1.19-2.14 \mathrm{mg} / \mathrm{kg}$ ) winter wheat samples: they were debranned and undebranned, and we investigated the flour's and the by-products' (coarse, fine bran) toxin content changes. SATAKE lab-debranner was used for debranning and BRABENDER lab-mill for the milling process. Without debranning, two sample flours were above the DON toxin limit $(0.75$ $\mathrm{mg} / \mathrm{kg}$ ), which are waste. By minimum debranning (and minimum debranning mass loss; $6-8 \%$ ), our experience with whole flour is that the multi-stage debranning measurement significantly reduces the content of the flour's DON toxin, while the milling by-products, only after careful consideration and DON toxin measurements, may be produced for public consumption and for feeding.
\end{abstract}

\section{Introduction}

One of the most important factors to improve the way of life of humans is ensuring healthy foods. Food safety deserves special attention: cereal grains

Keywords and phrases: wheat kernel, DON toxin, scalping, debranning. 
and animal feed are infected by the mycotoxins of moulds at variable rate and in variable amounts. We eat grain-based products every day, so it is essential to minimize the material toxin contamination. The mould of the largest food and feed safety hazards caused by the Fusarium fungus species is called mycotoxicosis (Raffaseder, 2003; Laczay, 2004; Reiss, 1981). Grain processing requires that the mycotoxin content stay in the grist (flour, bran, germ etc.) under the regulation (EC 1881/2006) limits (Weidenbörner, 2001; Mesterházy, 2002).

One of the most important, most dangerous toxins is the deoxynivalenol (DON), which inhibits protein synthesis and the autoimmune system (Mesterházy, 2007; Szeitzné et al., 2009), and in extreme cases it can cause cancer (Marasas, 1995). Most of the Fusarium toxin formation is stable, resistant to food treatments and responsive to heat (Hopmans \& Murphy, 1993; Scott, 1990). Fusarium toxins are especially on the wheat grain surface and the outer layer of the hull; so, the surface cleaning, before the grinding - as a toxin reducing process - comes into view (Bottega et al., 2009; Brera et al., 2006).

During our experiments, we applied paring of the wheat grains, which is a new surface treatment (debranning) procedure in milling technology to investigate the effect of this technique on the ability of decreasing mycotoxin contamination. The most common and the most abundant toxin is the Fusarium toxin, the DON (deoxynivalenol), so we measured the amount of this toxin by using different debranning times and the wheat contamination was also different.

Tolerable daily intake (TDI) values of DON for adults and infants were found to be 3 and $1.5 \mu \mathrm{g} / \mathrm{kg}$ body weight, respectively (Kuiper-Goodman, 1985). Therefore, we measured the DON content of the milling fractions of wheat samples with different contamination level, using various degrees of paring by using liquid chromatography-mass spectrometry (HPLC-MS), which has become the most frequently used technique in mycotoxin analysis (Zöllner \& Mayer-Helm, 2006).

\section{Materials and methods}

\section{Materials}

Experiments were performed at four different places, from different vintages and the wheat had different toxin contaminations.

Sample 1: 2008, naturally infected wheat (Gabonakutató Ltd, Szeged), DON content: $0.75 \mathrm{mg} / \mathrm{kg}$. 
Sample 2: 2008, Fusarium strains, artificially infected wheat (Gabonakutató Ltd, Szeged), DON content: $1.19 \mathrm{mg} / \mathrm{kg}$.

Sample 3: 2010, naturally infected mill wheat (BÁF Ltd., Szeged); DON content: $1.15 \mathrm{mg} / \mathrm{kg}$

Sample 4: 2010, naturally infected wheat, which was excluded from the milling process (Szatmári Malom Ltd., Jászberény), DON content: $2.14 \mathrm{mg} / \mathrm{kg}$.

\section{Debranning experiments}

We modelled the PeriTec technology with a laboratory-size, batch-operating horizontal debranning machine by SATAKE. The main part of the equipment is a cylindrical working space delimited by a perforated plate. In this working area, there is a horizontal-spindle, corundum-covered grinding wheel rotating. The operation of the machine is batch-type; $200 \mathrm{~g}$ of wheat can be treated at a time. After tempering the samples to a moisture content of $15 \%$, we leave the samples to rest for 12 hours. $2 \mathrm{~kg}$ of samples were used in the experiment, 10 repetitions were made for each sample. The debranning time was: 10, 20 (one time, $30 \mathrm{~s}$ ) and $40 \mathrm{~s}$.

\section{Grinding}

The undebranning and debranning samples were ground by BRABENDER Quadrumat Senior laboratory mill. The device has $2 \times 2$ rollers and sieve classification. The roll pairs are fixed; four rolls and three roll gaps grind the wheat. The grinding takes place in two stages and there are three fractions: flour, fine bran and coarse bran.

\section{Determination of DON toxin content}

Briefly, the DON toxin content of the samples was determined by using an Agilent 1100 HPLC system containing a well-plate autosampler, a quaternary pump, a column thermostat and an Agilent 1946A quadrupole mass spectrometer equipped with an electrospray ion source. The homogenized grist samples $(1 \mathrm{~g}$ each) were extracted with $4 \mathrm{ml}$ mixture of acetonitrile/water $(84 / 16 \mathrm{v} / \mathrm{v})$ in polypropylene centrifuge tubes (10 $\mathrm{ml}$ volume) at room temperature for $120 \mathrm{~min}$, by using an overhead shaker, and centrifuged at 10,000 x g for 10 min. $750 \mu \mathrm{l}$ volume of the supernatants were pipetted into the well plate of the HPLC autosampler and subsequently analysed. HPLC separations were performed on a Phenomenex, Kinetex C18 column $(50 \times 4.6 \mathrm{~mm}, 2.6 \mu \mathrm{m})$ at 
a flow rate of $0.8 \mathrm{ml} / \mathrm{min}$ by using a binary gradient of acetonitrile and water. The solvents were supplemented with $0.1 \%$ formic acid.

The protonated DON molecules $\left(\left[\mathrm{M}^{+} \mathrm{H}\right]^{+}\right)$were detected at $\mathrm{m} / \mathrm{z}$ value of 297 , using the SIM mode of the mass spectrometer. Internal standard quantitation was performed by using a Romer Labs (Tulln, Austria) ${ }^{13} \mathrm{C}_{15}$ DON standard.

\section{Results and discussion}

Table 1 shows the results. From the wheat samples, three were under the limit $(1.25 \mathrm{mg} / \mathrm{kg}$ ) and one sample (Sample 4) had DON toxin content above the limit $(2.14 \mathrm{mg} / \mathrm{kg})$. During the debranning, $6-8 \%$ of hull was removed, which caused the DON toxin content a significant reduction (reduced to half the initial toxin content) (Figure 1). As the result of the intense debranning, Sample 4, as "technological waste," was good (the DON content reduced under the toxin limit: $1.14 \mathrm{mg} / \mathrm{kg}$ ) for the milling process. The debranning loss $(10-13 \%)$ is not proportional to the weight loss values in the toxin content reduction; so, the toxin contamination is concentrated on the outer surface of the grain.

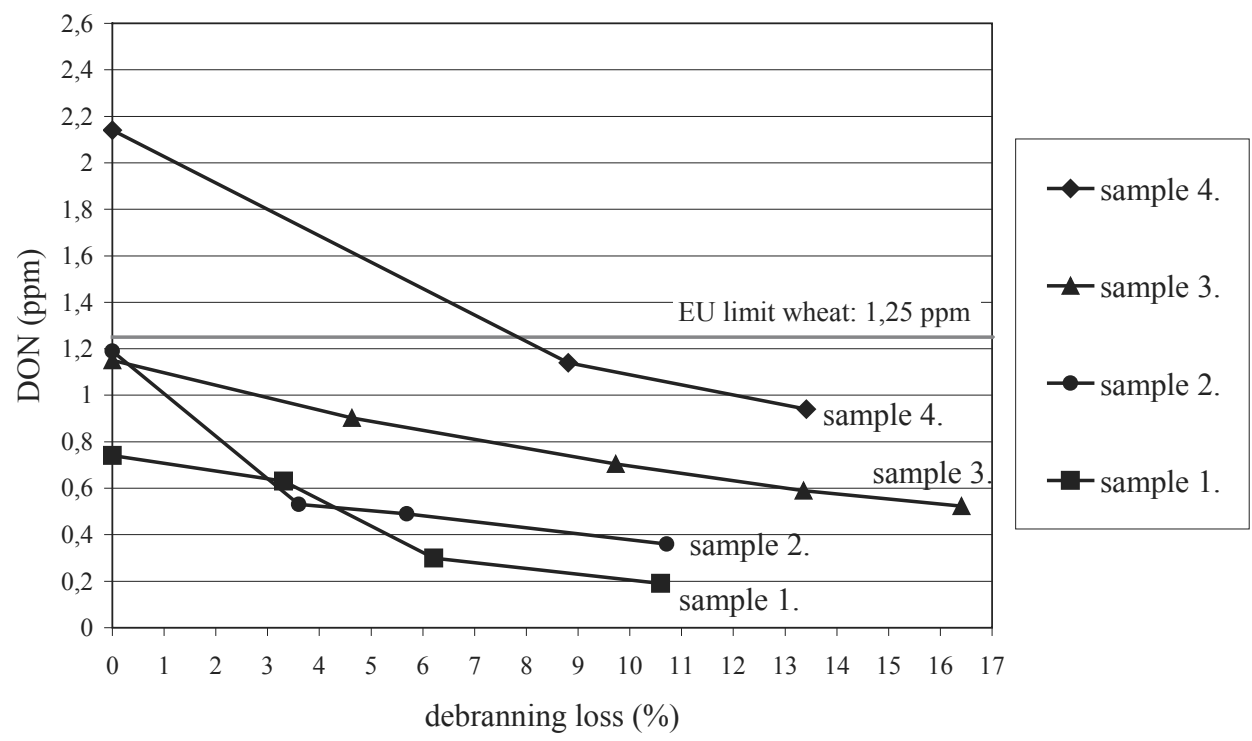

Figure 1: DON toxin contamination changes of wheat during debranning 


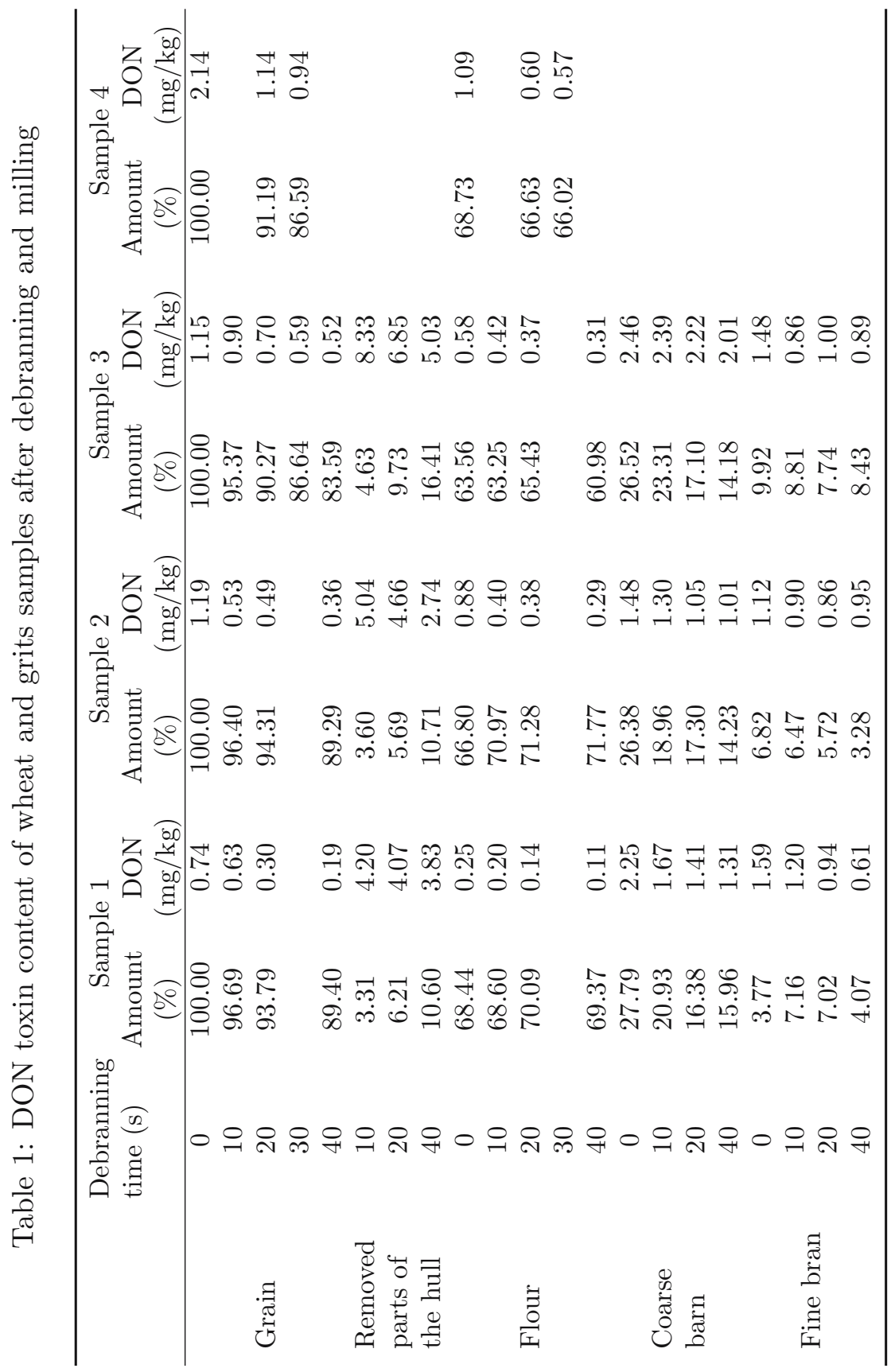


We measured $(0.75 \mathrm{mg} / \mathrm{kg})$ DON content above the limit in Sample $2(0.88$ $\mathrm{mg} / \mathrm{kg})$ and in Sample $4(1.09 \mathrm{mg} / \mathrm{kg})$ without debranning. Close to the limit was Sample 2 (grains DON: $1.19 \mathrm{mg} / \mathrm{kg}$ ), which will be "waste" flour without debranning, while with a minimum debranning loss $(\sim 3.6 \%)$ it will be consumed because the DON level of flour was reduced $(0.4 \mathrm{mg} / \mathrm{kg})$. The DON content of Sample 4, flour without debranning, is over the limit $(1.09 \mathrm{mg} / \mathrm{kg})$, but with the practical debranning (with $8.81 \%$ bran loss) the milling flour's DON toxin content $(0.6 \mathrm{mg} / \mathrm{kg})$ is under the health limit (Figure 2).

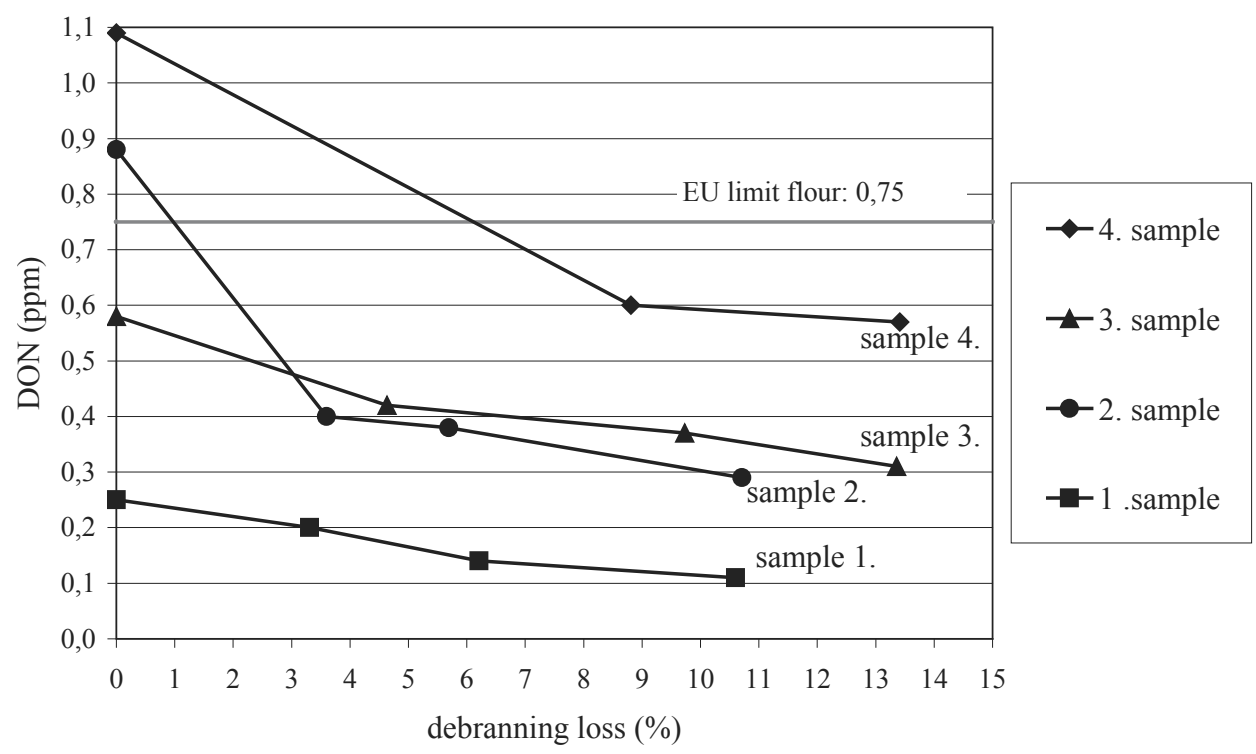

Figure 2: DON toxin contamination changes of flour during debranning

We examined 4 different DON-toxin-containing (0.74-1.15-1.19-2.14 mg/kg) winter-wheat samples: they were debranned and undebranned, and we investigated the flour's and the by-products' (coarse, fine bran) toxin content changes. The toxin content of the removed part of the hull was determined only for the first three samples: the amount was in connection with debranning time $(10$, 20, 40 sec.): at least, debranning: 3-4\%, medium debranning: 6-9\%, intensive debranning: $10-16 \%$.

In the first stage, we received the highest DON content, $4-8 \mathrm{mg} / \mathrm{kg}$; with further debranning, the DON contamination decreases. It shows that the mycotoxin is generally on the outer bran layer, where it is strongly adsorbed during debranning; the toxin content is smaller in the inner bran layers. 
The same conclusion is reinforced in the DON toxin results of coarse and fine bran fractions: a minimal DON contamination $(0.74 \mathrm{mg} / \mathrm{kg})$ excludes the eating of bran. The by-product of milling (coarse, fine bran), which is close to the limit $(1.19,1.15 \mathrm{mg} / \mathrm{kg} \mathrm{DON})$, is "hazardous waste".

\section{References}

[1] G. Bottega, C. Cecchini, M. G. D'Egidio, A. Marti, M. A. Pagani, Debranning process to improve quality and safety of wheat and wheat products, Tecnica Molitoria International (yearly issue), 2009, 67-78.

[2] C. Brera, C. Catalano, B. De Santis, F. Debegnach, M. De Giacomo, E. Pannunzi, Effects of industrial processing on the distribution of aflatoxins and zearlenone in corn-milling fractions, Journal of Agricultural and Food Chemistry, 54. (2006) 5014-5019.

[3] EC 1881/2006.

[4] E. C. Hopmans, P. A. Murphy, Fumonisins: mycotoxins produced by Fusarium moniliforme. In: W. R. Bidlack \& S. T. Omaye, (eds.), Natural protectants against natural toxicants. Technomic Publ., (1993) 61.

[5] T. Kuiper-Goodman, Potential human health hazard and regulatory aspects. Mycotoxins: a Canadian perspective. In: P. M. Scott, H. L. Trenholm and M. D. Sutton (eds.). NRCC 22848. 185. (1985) 103-111.

[6] P. Laczay, Állati eredetű élelmiszereink kémiai-toxikológiai biztonsága 3. Biológiai eredetű szennyező anyagok. Magyar Állatorvosok Lapja, 126. (2004) 371-380.

[7] W. F. O. Marasas, Fumonisins: their implications for human and animal health, Natural Toxins, 3. (1995) 197-198.

[8] Á. Mesterházy, A mikotoxinok és az élelmiszerbiztonság, a megoldás lehetőségei, A kémiai tudományok osztályának a 2002. májusi közgyüléshez kapcsolódó tudományos ülései. 2012. 10. 20.

[9] Á. Mesterházy, Mikotoxinok a gabonatermesztésben: az élelmiszerbiztonsági kihívás, Élelmiszervizsgálati Közlemények: Élelmiszerminőség - Élelmiszerbiztonság (Különszám). 53. (2007) 38-48. 
[10] C. Raffaseder, Einfluss von Moniliformin und Beauvericin auf Leistungsund Physiologische Parameter von Mastputen. Dissertationsarbeit, Universität für Bodenkultur, Wien. (2003)

[11] J. Reiss, Mycotoxine in Lebensmitteln. Gustav Fischer Verlag Stuttgart New York (1981)

[12] P. M. Scott, Trichotecenes in grains. Cer. Foods World. 35. (1990) 661666.

[13] M. Szeitzné Szabó, A. Hámos, J. Cseh, Á. Ambrus, M. T. Szerleticsné, Gabonaalapú élelmiszerek fuzáriumtoxin szennyezettségének csökkentési lehetőségei, Magyar Élelmiszer-biztonsági Hivatal tájékoztatója (2009)

[14] M. Weidenbörner, Encyclopedia of food mycotoxins, Spinger-Verlag, Berlin, (2001) 173.

[15] P. Zöllner, B. Mayer-Helm, Trace mycotoxin analysis in complex biological and food matrices by liquid chromatography-atmospheric pressure ionization mass spectrometry. Journal of Chromatography A., 1136. (2006) 123-169. 